\title{
(켜이
}

Research and Evaluation in Education

Volume 1, Number 2, December 2015 (pages 199-211)

Available online at: http://journal.uny.ac.id/index.php/reid

\section{THE USE OF MALCOLM BALDRIDGE METHOD FOR FORMULATING STRATEGIC PLANNING IN TECHNOLOGICAL AND VOCATIONAL EDUCATION}

\author{
${ }^{1)}$ Subarno; ${ }^{2)}$ Sukamto; ${ }^{3)}$ Sutarto \\ ${ }^{1)} 11$ Maret University, Indonesia; ${ }^{23)}$ Yogyakarta State University, Indonesia \\ ${ }^{11}$ myharno@yahoo.com; ${ }^{2}$ sukamto@uny.ac.id; ${ }^{3)}$ sutarto@uny.ac.id
}

\begin{abstract}
The article describes the results of a study evaluating the performance of technological and vocational education (TVE) by the use of Malcolm Baldrige method. The data on the performance were used in order to reveal its strengths and weaknesses. Based on the performance strengths and weaknesses, a competitive strategy could be formulated to improve TVE quality. First, performance measurements by using Malcolm Baldrige criteria were done in seven study programs in different universities. Second, the results of the performance measurements were analyzed and described. With the data resulting from the performance measurements as the basis of the analysis, the and weaknesses of TVE performance might be found. Third, a strategy was developed. Based on the performance strengths and weaknesses, a performance improvement strategy might be formulated in order to raise the quality level within the educational process of TVE. The research results indicate that for the performance level in the seven universities under study, the achieved scores range from 526 to 711 points. These results show that the performance of TVE study programs in Indonesia is in the categories of education leader and producer of education leader. On the basis of those categories, each study program might formulate its own competitive strategy in order to improve TVE performance so that the educational process might also improve in terms of its quality level.
\end{abstract}

Keywords: Malcolm Baldrige, TVE, competitive strategy, strategic planning 


\section{Introduction}

Education is a system in which there are many processes that form sub-systems. These processes occur within an educational environment, which, in wide sense, is something that becomes the domain of review within educational strategic problems. A comprehensive educational planning will always be related to educational process and sub-systems within an educational system. The educational system referred to is the system that includes activities of resource planning, curriculum planning, learning method planning, and so on.

Planning is a basic and strategic managerial function that provides direction in an activity implementation in order to achieve educational objectives. Educational planning is one of the key factors to achieve effective and efficient education, and also training activities so that the planning might produce graduates that meet the society's needs/ demands (Leslie, 2005, p.9).

According to Indrajit (2004, p.11), in its realization, the existence of educational planning in all educational degrees has been regarded as a complimentary factor or an elaboration of the institutional chief policy. In other words, most educational plannings in educational institutions are merely a realization of a chief's demand or expectation. Oftenly, the formulated objectives are not in accordance with the planning so that they cannot be achieved appropriately. It is also supported by the low number of educational planning staffs who are able to understand the planning process and mechanism comprehensively. In addition, the position of planning department has not been made as a determining factor for the position of an educational institution both in the micro- and macrolevels. Such condition causes the contribution of educational planning toward the attainment of vision, mission and objectives of institutions in several degrees, including in universities, has not been maximal.

Ridwan (2008, p.26) explains that in essence, an institution is said to have a wellqualified planning if it optimally and consistently has orientation toward the ability to provide well-qualified product/service for customers all the time. There are several criteria that might be used for measuring wellqualified educational planning, namely: the focus on problem-solving efforts, the investment toward human resources, the efforts to treat complaints as feedbacks for selfimprovement, the possession of planning/ policy strategy for attaining the quality, the efforts to pursue improvement by involving as many stakeholders as possible, the possession of clear evaluational strategy, the possession of long-term planning, and the view of quality as a part of culture.

Based on these explanations, it can be concluded that universities need a corporatelike management. The basis of all managerial efforts is planning. A university is said to have a well-qualified planning if it is based on the stakeholders' satisfaction-oriented educational planning. In order to achieve the objective, all of the activities in a university should be based on the well-prepared planning both the short-term, the intermediate, and the longterm one. Then, the planning approach might meet the stakeholders' expectation in the strategic planning, which is, a long-term planning that decides the viability of an organization. Thereby, there should be efforts in order that the formulation of a university's strategic planning might be made in an appropriate way.

In reality, strategic planning has not been made as the basis of higher education management in Indonesia. This matter is apparent from the few science and technology innovations generated by higher education instutions. Scientific publications of research reports in Indonesia, both on national and international level, are still few, compared to those in developed countries. Such condition is assumed to be caused by the fact that the movement of activities has not been based on the planning. Therefore, this is the time for higher education to be managed like a corporate that implements activities based on a planned strategy which is implemented accurately, precisely and correctly.

Bryson (1999, pp.17-18) states that strategic planning is a planning that departs from the organizational vision, mission and 
values and that aims to meet the stakeholders' needs and expectation. The strategic planning that relates the vision, the mission, the values and the objectives to the analysis of internal and external environment will make the organization find the most strategic direction both in the present and in the future.

Within the university quality assurance system, it has been mentioned that each university should have a strategic planning, because strategic planning is the main reference for the achievement of all quality assurance within the system. In order to formulate the strategic planning appropriately, the design process should be accompanied by the environmental analysis, tracer study, and normative review. Furthermore, for the environmental analysis, the designers might implement the SWOT analysis method; and for the tracer study, the designers might involve the related stakeholders (Department of National Education, 2010, pp.21-25).

Regarding strategy, Abraham (2006, p.7) describes that strategy is how a company actually competes. The statement implies that strategy shows how an organization is actually able to perform the activities based on the possessed potentials. Allio (1998, p.8) defines that strategy is the art of deploying resources toward market opportunities in a way that distinguishes a bussines from its competitors. This statement implies that strategy is an art of using every single resource to attain a market opportunity by doing something different from what the competitor does. Based on the two statements, each university is demanded to intelligently define a wellplanned strategy to achieve the objectives.

Law Number 14 Year 2005 Article 14 regarding Teacher and Lecturer and Government Regulation Number 74 Year 2008 regarding Teacher Certification mention that Teacher Education Institutions or TEI (Indonesian $=$ Lembaga Pendidikan Tenaga Kependidikan or LPTK) is a part of university that aims to prepare teachers professionally. In order to achieve the objective, the institutions should manage the abundant resources and have a great role in educating the skillful and educated Indonesian human resources. Consequently, the institutions are demanded to have an appropriate strategic planning in order to be able to take over the market competitively.

Technological and Vocational Education (TVE) Department is one of the subsystems in the national education, especially as a part of Teacher Education Institution (TEI). As a part of TEI, TVE which in its vision, mission and objectives should be able to produce capable teachers as the graduates, is demanded to implement good quality education. The development and changes of science and technology altogether with the rapid global dynamic demands makes TVE as a part of TEI (TEI-TVE) must be able to adapt itself. TEI-TVE that manages and produces teacher candidates in TVE Department should pursuit changes and improvements in order to increase educational quality. In other words, TEI-TVE should be able to equip the graduates with the ability in the teaching and vocational domain altogether at the same time. Thereby, the demand impacts the planning in TEI-TVE; the planning in TEI-TVE should be designed on the basis of strategic planning.

Managing TEI-TVE effectively and efficiently is a certainty in an effort of generating good quality products/services. Prosser (1950, p.231) states that the administration of vocational education will be efficient in proportion as it is elastic and fluid rather than rigid and standardized. The statement implies that the administration (management) of vocational education will be efficient if the administration (management) is implemented under good balance by holding the principles of being flexible, dynamic and standardized. TEI-TVE is different to any other general educational institution. The characteristic that differentiates TEI-TVE from other general educational institutions is that the students are emphasized to master certain skills in addition to the knowledge. To support the objective, TEI-TVE demands more complex facilities compared to the general ones. In addition, TEI-TVE also experiences greater dynamics with the stakeholders compared to the general education; as a result, it has been common that the principles of being flexible, dynamic and standardized are inherent to TEI-TVE. 
In order to generate well-qualified graduates who are relevant to the market demand, the government has issued several regulations that control the improvement of educational quality in Indonesia. In Law Number 20 Year 2003 regarding the National Education System, article 51 verse 2 and article 91 verse 1 mention that each university, both state and private, is demanded to ensure its educational quality. To ensure its quality of education, each university is demanded to have strategic planning. In Government Regulation Number 8 Year 2008 regarding the Strategic Planning Systematic Design Guidelines, it is mentioned that the strategic planning includes environ-mental assessment and institutional performance achievement assessment. Law Number 25 Year 2004 regarding the Design Content and Reference defines that the TEI strategic planning is designed by referring to environmental analysis, performance assessment, and market/industrial demand. Law Number 12 Year 2012 article 62 defines that university has autonomy to manage itself as the center of tri dharma (teaching, research, and community service) implementation in the university.

Based on the afore-mentioned regulations, TEI-TVE within the educational management should have a strategic planning that is designed based on the environmental analysis and institutional performance assessment. Environmental analysis is implemented in order to scan the internal and external factors used for planning the strategy. On the other hand, the performance assessment is implemented in order to measure how great the power of an institution is in implementing the strategy. The environmental analysis and performance assessment might be performed from the rectorate level to the department/ study program level depending on the scope of the strategic planning.

Based on the initial study toward the graduates of TEI-TVE from the Engineering Education Study Program and Construction Education Study Program, both the ones who teach at vocational high schools and the ones who work in the construction company, it was found that these graduates are quite good in terms of knowledge competence; however, in terms of skill and attitude competence, these graduates should improve themselves. Most of the principals state that the graduates of TVE generally have sufficient knowledge competence, but they are poor in terms of skill and attitude competence. Whereas, in order to work in industries or in vocational high schools as teachers, they should master the skill and attitude competence well. From the aspect of management, the observation and interview data from the initial study toward the team of strategic planning designers in three TEI-TVEs show that the departmentstudy programs have already had strategic planning; however, the existing strategic planning still have to face several problems. The problems might be seen from the fact that the existing strategic planning has not reflected the conditions that might meet the institutions' vision.

The measurement of study program performance has not been performed as well; as a result, the stakeholders do not attain any document in relation to the performance of each study program. Based on the interview, it is found that the parties responsible for the strategic planning in overall $(100 \%)$ stated that the possession of strategic planning that has been designed through the appropriate process/method is heavily necessary.

As a university which, specifically, produces teacher candidates for the technological and vocational education, TEI-TVE is heavily necessary for establishing a system of performance measurement to create vision and mission as a part of quality assurance system (Wikipedia, 2008, p.6). A good system of performance measurement should be comprehensive and integrated to all units and activities. The performance indicators that should be formed will not only be in the form of financial ones, but also non-financial ones (Wheelen, 2003, p.24). In relation to the statement, Malcolm Baldridge is one of the tools that might be operated for measuring the performance of an educational institution. Therefore, the study presents the results of performance measurement on the educational implement-ation in TEI-TVE based on the criteria of Malcolm Baldridge in order to improve the quality of TEI-TVE education. 
According to Gasperz (2011, p.8), the performance of an institution, either profitable or non-profitable, should be measured. Knowledge regarding the performance data is very useful for designing strategic planning in the related institution. Furthermore, according to Indrajit (2006, p.12), a university should implement a strategic planning that has been designed based on the performance data because it is the main reference in achieving university quality standards.

\section{Performance Measurement}

A measurement occurs if a certain measuring tool is operated to ensure the weight, height or other characteristics of an object measured. In daily life, people often perform measurement; however, within a study, the measurement should meet certain requirements. The measurement in the study itself should consist of number provision on an empirical event in accordance with certain regulations (Cooper \& William, 1996, p.6).

Performance (job achievement) is a result that an individual would like to achieve in performing the duties given to him/her based on the capability, experience, determination, and period (Swasto, 1996, p.4). There are several measurement tools that might be used, namely Balanced Scorecard, Quality Management System ISO 9001, Malcolm Baldridge National Quality Award or Malcolm Baldridge Award (Gasperz, 2001, p.15).

Performance measurement in TEI-TVE is very important to be conducted because by measuring performance, the stakeholder of an organization might find important information regarding the educational implementation. The measured information might be used by the deans and staffs of the institution as the main starting point in improving the graduates quality and relevance. If TEI-TVE is unable to measure its performance, then the institution will have difficulties in performing its managerial duties (Indrajit, 2006, p.36).

Performance Measurement by Means of Malcolm Baldridge Method

Performance analysis should be conducted as the basis of decision making in relation to the strategy scale of priority.
Balance Scorecard balances internal and external factors. The analysis of institutional performance might be used for balancing the existing resources and selected strategy. One of the basic questions is whether the existing resources are ready to implement the strategy that has been selected or not. Furthermore, an organization should also consider whether the leaders are able to mobilize their staffs in order to implement the strategy or not. In addition, the organization should consider whether the existing budget is sufficient or not as well. There are more aspects that an organization should consider in relation to the strategic planning. Gasperz (2011, p.95) describes that Malcolm Baldridge Criteria for Education (MBCfE), also known as The Baldridge Assessment, is a measured and systematic method that might accomodate such questions. Since 2009, the method has been adopted by more than 70 countries, including Indonesia; Indonesia adopts the system into Indonesian Quality Award (IQA).

Research and development also implements MBCfE method for assesing the performance with the following objectives: to increase the awareness toward the quality, to identify the needs for well-qualified quality, to introduce multiple methods of educational quality measurement, and to share (publish) information regarding the success and the advantages of quality strategy. The targets that will be achieved by employing MBCfE is to provide an alternative model that might be used as a reference for improving the quality management continuously. The MBCfE is managed by an international organization named National Institute of Standards and Technology (NIST), which defines that:

The Malcolm Baldrige Education Criteria for Performance are the basis for organizational self-assessments, for making Awards, and for giving feedback to applicants. In addition, the Education Criteria have four other important purposes: to help improve organizational performance practices and capabilities, to facilitate communication and sharing of best practices information among education organizations and among organizations of all types, to foster the development of partnerships involving schools, businesses, human service 
agencies, and other organizations via related criteria, and to serve as a working tool for understanding and improving organizational performance, and guiding planning and training (NIST 2000, p.2)

Based on the definition, MBCfE is one of the tools that might be used for improving the organization performance completely and continuously by means of measurement, and providing feedbacks regarding organizational performance in providing good quality product and service. Most of the managerial experts also regard MBCfE as self-evaluation. The superiority of Baldridge criteria is the ability to provide overall and integrated assessment that might asssist a visionary leader. The advantage of the criteria is the ability to improve the study program performance, lead the planning design, provide multiple information on the best practices, and communicate the best practices to all institutional working departments/units.

Witnessing the superiority of MBCfE and the development of educational quality system that has been well-implemented in America, the wave of adoption toward the quality system has been able to encourage the system of quality monitoring in the educational institutions spread throughout the countries around the world such as New Zealand and Australia. In Indonesia, a systematic selfevaluation based on the system of quality monitoring in educational institutions is a new matter and has not been implemented systematically, whereas quality is the main requirement for encountering the full-ofcompetition age. Without good quality in each product and service that has been generated, the customers will quickly switch to other organizations in order to get better quality goods and services.

MBCfE assessment is conducted toward seven criteria/categories with a total score of 1000 . The seven criteria are leadership (120 points), strategic planning (85 points), customer and stakeholder (85 points), information and analysis (90 points), human resources ( 85 points), process management (85 points) and results of activity (450 points). According to NIST, the stipulation of the maximum score for each category is based on how great the effect of those criteria on the performance of an institution. The following sections describe briefly each of criteria/ categories that have been directly applied to the context of study program in the university (NIST, 2000, p.12).

\section{Leadership (120 points)}

A strong leadership in a study program is necessary in an effort to integrate quality, including performing the social responsibility. The category of leadership assessment is an effort to test and evaluate the commitment and involvement of the program leaders in creating and preserving the quality values, such as customers' (university students) satisfaction.

\section{Strategic Planning (85 points)}

The category of strategic planning measures how a study program develops the plan and objective of an action. Another aspect that is measured by the category is how to choose the selection and the plan of a strategic action in the implementation and in the changes, if the related situation changes, altogether with the improvement. The item explains how the study program implements the strategy and the target of strategic results; in addition, the item also explains how to reveal the strategic challenges and objectives.

\section{Focus on Customer and Stakeholder (85 points)}

Focusing on customers and stakeholders measures how a study program determines customers' needs, expectation and loyalty. Another aspect measured by this category is how the study program establishes relationship with the customers and determines the main factors in pursuing the customers' objectives, satisfaction and loyalty. TVE customers are university students, vocational high schools, and industries.

\section{Information and Analysis Management (90 points)}

The category of information and analysis management measures how a study program selects, attains, analyzes, regulates, and develops data, information, and asset of the possessed knowledge. Moreover, the category also measures how a study program 
reviews the performance. It describes how a study program measures, analyzes, arranges, reviews, and develops its performance as a producer of vocational teachers.

\section{Human Resources (85 points)}

The categoy of human resources, in this case the lecturers and staffs, measures/detects the ability of a study program to evaluate the employees' capability and capacity as well as to establish a conducive working environment for the sake of good performance. The category of human resources also measures how a study program mobilizes, manages, and develops the human resource potentials in accordance with the study program's vision, mission, strategy, and action plan.

\section{Process Management (85 points)}

The category of process management measures how a study program designs, manages and also improves working and educational system in order to meet the customers' and stakeholders' expectation as well as to achieve the study program's success and continuity. In addition, the category also measures how a study program overcomes the problems in an emergency.

\section{Education Results (450 points)}

The category of education results measures the performance and improvement of a study program in the scope of education, together with the other service results, customer satisfaction, financial performance, human resources results together with the working system, operational performance, and the leader's responsibility. The study program performance level will also be measured in comparison to other competitors within the same domain.

Harry and Hertz (2011, p.4) mention that in order to measure each category, a team of strategic planning together with the policymaking parties should formulate indicators by referring to the following concept:

\footnotetext{
A major consideration in performance improvement involves the selection and use of performance measures or indicators. The measures or indicators you select should best represent the factors that lead to improved
}

student, operational, and financial performance. A comprehensive set of measures or indicators tied to student, stakeholder, and organizational performance requirements represents a clear basis for aligning all activities with your organization's goals.

Based on the concept, assessment indicators lead to the involvement of all components in each category. Then, the team of strategic planning elaborates the indicators that have already formulated into a list of questions or statements to be tested to the respondents for measurement. The respondents who measure the study program performance are the lecturers, excluding the head and secretary of the study program. The measurement should be performed under such manner to avoid ambiguity and subjectivity within the assessment. A principle that the team of strategic planning should hold on to is that the objective of performance assessment and evaluation is not to ruin a reputation, but to find how big the value possessed by all of the staffs in a study program is. The results of evaluation becomes an official document of a study program that might be used for improving the quality continuously. Thereby, the assessment should be done honestly without any concern. In the study, the indicators of MBCfE assessment are developed based on the criteria proposed by Gasperz (2011, p.218) and by NIST (2000, p.12).

Performance Measurement Steps by means of MBCfE

According to NIST (2000, pp.13-29), in general, the steps for measuring the performance of a study program by the use of MBCfE are as follows: (1) performing an initial survey toward the study program performance; (2) designing a list of MBCfE questions; (3) distributing questionnaires to respondents; (4) processing the data attained and adapting the data into MBCfE sub-categories; (5) performing assessment toward each category and subcategory of MBCfE; (6) performing overall assessment to find the performance final score; and (7) having discussions to improve the organizational performance. The category of assessment results is presented in Table 1. 
Table 1. Description of Performance Measurement Results by Means of Malcolm Baldridge

\begin{tabular}{ccc}
\hline Score & Criteria & Note \\
\hline $876-1000$ & World Leader & \\
$776-875$ & Benchmark Leader & Excellent \\
$676-775$ & Industry Leader & \\
& & \\
\cline { 3 - 3 } $576-675$ & Emerging Industry Leader & \\
$476-575$ & Good Performance & Average \\
$376-475$ & Early Improvment & \\
& & Poor \\
$276-375$ & Early Result & \\
$0-275$ & Early Development & \\
\end{tabular}

Strategic Planning

Abraham (2006, p.9) states that strategic planning is a process, that is, a series of steps followed by a company collectively trying to agree on where it is going (i.e., vision) and the way it will get there (i.e., strategy). The theory implies that the objectives that have been formulated by an organization should be achieved by means of systematic and commonly agreed methods. The agreement is necessary under the following reason: there might be multiple methods for achieving the organizational objectives and there should be support from all of the existing resources to achieve the organizational objectives. Therefore, an organization should perform agreement under certain methods that have the biggest profit of implementation.

Alison (2005, pp.1-2) describes that strategic planning is a systematic process through which an organization agrees on priorities that are essential to its mission and are responsive to the environment; strategic planning guides the acquisition and allocation of resources to achieve these priorities. The definition implies that a strategy is a series of systematic processes. Thereby, in order to formulate the strategy, there should be a method that might measure the performance clearly. A good strategic planning should be accompanied by a sequence of priority in the strategy achievement. In order to formulate the strategy and the strategy achievement, there should be a commitment from all of the human resources within the organization.

In an opinion proposed by Handoko (2003, p.42), a strategic planning is a process of selecting the organizational objective, determining the strategy, policy, and strategic programs necessary for the organizational objectives, and defining the methods that ensure that the strategy and policy might be implemented. In brief, a strategic planning is a process of long-term planning designed and implemented for deciding and attaining the organizational objectives.

Bryson (1999, p.24) provides an explanation of a strategic planning concept, namely that a process of any strategic planning will be useful only if it assists the reasoning and action of the decision-makers strategically. A strategic planning is not the objective of the strategic planning itself; instead, a strategic planning is a group of concepts which is designed for assisting the leaders in making important decisions and taking important actions. Even if the process of a strategic planning causes difficulties in the reasoning and strategic action, the process of planning should be put aside instead of the reasoning and action.

Based on the conception of strategic planning, it can be concluded that a strategic planning is a process that contains the steps for achieving certain organizational objectives under certain methods appropriate-ly. A strategic planning is a long-term planning that decides the viability of an organization. Due to the long term operational implementation, a strategic planning should be accompanied by a short term planning and an intermediate term planning. The inter-related key of success in performing strategic planning is to perform the strategic planning with strategic paradigm under strategic analysis.

\section{Research Method}

Approach

The study employed qualitative and quantitative approach. For the data gathering method, the researchers selected observation and questionnaire distribution. The observation was conducted toward seven study programs in different TEI-TVE. For the data gathering instrument, the researchers employed an observation sheet and questionnaire. The questionnaire was designed based on the 
official guidelines of Malcolm Bridge Criteria for Education. The questionnaire validity and reliability was measured by employing product moment correlation and SPSS version 16. The object of the study was eight study programs from four different TEIs. The respondents who were involved in the study were the lecturers and administrative staffs in each study program. Table 2 presents the names of the study programs and the number of the respondents.

Table 2. Object and Number of Respondents for the Performance Measurement

\begin{tabular}{clcc}
\hline No & Study Program & TEI & $\begin{array}{c}\text { Number of } \\
\text { Respondents }\end{array}$ \\
\hline 1 & Construction Education & Surakarta State University & 22 \\
2 & Engineering Education & Surakarta State University & 23 \\
3 & Family Welfare Education & Sarjanawiyata Tamansiswa University & 7 \\
4 & Engineering Education & Yogyakarta & 12 \\
5 & Electroning Engineering Education & Cendana University East Nusa Tenggara & 8 \\
6 & Engineering Education & Cendana University East Nusa Tenggara & 10 \\
7 & Construction Education & Cendana University East Nusa Tenggara & 7 \\
\end{tabular}

\section{Data Type}

The data were divided into two categories, namely primary data and secondary data. Both of the data types were constructed in the form of quantitative and qualitative data. Primary data are the data which are attained from observation and questionnaire which is directly distributed to the respondents. Secondary data are the elaboration of the steps in attaining the primary data as having been written in the technical explanation of data gathering. Secondary data were attained from the library, the documents from the study program in the form of self-evaluation and strategic planning, legal products in relation to education and strategic planning, and sources from the internet which are relevant to the study. The secondary data were intended to attain theoretical foundation that led to the completeness of topic explanation so that the conclusion that the researchers wanted to attain would have scientific and rational load. The steps for attaining the data are explained in the following sections.

\section{Pre-Survey}

Pre-survey was conducted in Engineering Education Study Program and Construction Engineering Study Program, Faculty of Teacher Training and Education, Surakarta State University, and Engineering Education Study Program and Construction Study Program, Sarjanawiyata Tamansiswa University, Yogyakarta. The aim was to find how far the process had been implemented to students.

\section{Observation}

Observation is an activity performed to find all elements related to the strategic planning implementation in the study program being observed. By conducting observation, necessary data for the study were found.

\section{Questionnaire Distribution}

The questionnaire that had been stated as valid and reliable was distributed to all respondents who influenced the implementation of strategic planning. The respondents for MBCfE were non-structural lecturers in each related study program. 


\section{Data Gathering Instrument}

Instrument, as the data gathering tool, was intended to measure the validity, practicality and effectiveness of the model and instrument itself. To attain good data, the instrument should be developed well. Within the study, the instrument implemented by the researchers was MBCfE research. MBCfE research instrument in the form of questionnaire was used to attain data on the level of study program performance in Technological and Vocational Education Department. The research instrument was developed based on the manual issued by the National Institute of Standards and Technology (NIST).

Consecutively, the steps taken by the researchers in the study were performing initial survey toward the study program's performance qualitatively, designing questionnaire based on the Malcolm Baldridge criteria, distributing questionnaire to the respondents, processing the data that had been attained in accordance with Malcolm Baldridge category, performing assessment toward each category and sub-category that had been made in the form of percentage based on the table of Scoring Guidelines Malcolm Baldridge, performing overall assessment to attain final score on the performance and performing analysis, and having discussion to provide useful recommendation to formulate competitive strategy.

\section{Findings and Discussions}

The performance measurement toward all of the objects was based on the Malcolm Baldridge criteria that covered seven categories. The results of performance measurement in the Construction Education Study Program, Surakarta State University for the leadership category were shown in Table 3.

Table 3. Criteria of Leadership Performance in the Construction Education Study Program

\begin{tabular}{|c|c|c|c|c|c|c|}
\hline \multicolumn{3}{|r|}{ Leadership Criteria (120 point) } & $\begin{array}{c}\text { Performance } \\
\% \\
\end{array}$ & $\begin{array}{c}\text { Sub-Criteria } \\
\text { Mean }\end{array}$ & $\begin{array}{l}\text { Sub-Criteria } \\
\text { Value }\end{array}$ & $\begin{array}{l}\text { Total } \\
\text { Score }\end{array}$ \\
\hline \multirow[t]{5}{*}{1} & \multicolumn{6}{|c|}{ Study Program Leadership (70 point) } \\
\hline & 1.01 & Chief of study program involvement level & $63 \%$ & & & \\
\hline & 1.02 & Commitment and consistence & $65 \%$ & & & \\
\hline & 1.03 & $\begin{array}{l}\text { Communication effectiveness for quality } \\
\text { improvement }\end{array}$ & $64 \%$ & & & \\
\hline & 1.04 & Leadership capability development & $70 \%$ & $65 \%$ & $70 \%$ & 45.72 \\
\hline \multirow[t]{11}{*}{2} & Quali & ity Management and Social & & & & \\
\hline & Resp & onsibility (50 Point) & & & & \\
\hline & 1.05 & Study program leadership accountability & $63 \%$ & & & \\
\hline & 1.06 & $\begin{array}{l}\text { Communication toward staff and custom- } \\
\text { er expectation }\end{array}$ & $59 \%$ & & & \\
\hline & 1.07 & $\begin{array}{l}\text { Support toward staff competence } \\
\text { improvement }\end{array}$ & $44 \%$ & & & \\
\hline & 1.08 & $\begin{array}{l}\text { Staff mentoring and strengthening toward } \\
\text { the importance of competence improve- } \\
\text { ment }\end{array}$ & $60 \%$ & & & \\
\hline & 1.09 & $\begin{array}{l}\text { Society response toward activity } \\
\text { implementation }\end{array}$ & $64 \%$ & & & \\
\hline & 1.10 & $\begin{array}{l}\text { Impact and advantage planning/ } \\
\text { calculation on the results of activities } \\
\text { toward society (customer) }\end{array}$ & $50 \%$ & & & \\
\hline & 1.11 & $\begin{array}{l}\text { Involvement in handling problems within } \\
\text { society (social) in the domain of edu- } \\
\text { cation }\end{array}$ & $58 \%$ & & & \\
\hline & 1.12 & $\begin{array}{l}\text { Evidences that support the social } \\
\text { responsibility }\end{array}$ & $38 \%$ & $55 \%$ & $50 \%$ & 27.250 \\
\hline & & & & Total & & 73.100 \\
\hline
\end{tabular}



Based on the results in Table 3, it is apparent that the involvement of a study program leader is $63 \%$ based on the average assess-ment performed by the respondents. Then, based on the items under assessment, the performance of the study program leader is $65 \%$, while the quality management is $54 \%$. The results of the average performance is multiplied by the scores that are attained in the Scoring Guidelines Baldridge Award; as a result, the total point for the leadership performance is 72.83 (the maximum point is 120 points).

Based on the calculation as presented in Table 3, the performance in terms of the other criteria is measured. Table 4 shows the results of the recapitulation of the performance assessment for the overall criteria in the Construction Education Study Program, and Table 5 for the Engineering Education Study Program.

Table 4. Point Recapitulation and Position Assessment on the Construction Education Study Program

\begin{tabular}{|c|c|c|c|c|}
\hline No & Criteria & $\begin{array}{l}\text { Point According to } \\
\text { MBCfE }\end{array}$ & $\begin{array}{c}\text { Point from the Assessment } \\
\text { Results }\end{array}$ & $\begin{array}{c}\text { Achievement } \\
(\%)\end{array}$ \\
\hline 1 & Leadership & 120 & 73 & 60.69 \\
\hline 2 & Strategic Planing & 85 & 51 & 59.51 \\
\hline 3 & Customer & 85 & 51 & 59.51 \\
\hline 4 & $\begin{array}{l}\text { Information \& } \\
\text { Analysis }\end{array}$ & 90 & 48 & 53.61 \\
\hline 5 & Human Resources & 85 & 54 & 63.00 \\
\hline 6 & Process Management & 85 & 47 & 54.93 \\
\hline \multirow[t]{2}{*}{7} & Results & 450 & 258 & 57.44 \\
\hline & Total & 1000 & 581 & 100.00 \\
\hline
\end{tabular}

Based on the results of the measurement (Table 4), the scores which are attained by the Construction Education Study Program is 581. The score implies that the performance of Construction Education Study Program earns the predicate 'average', and it belongs into the category of Emerging Industry Leader. The Emerging Industry Leader category implies that the Construction Education Study Program has entered the industrial area of the educational domain. In other words, Construction Study Program has approached the industrial competition-based organization management. By improving the performance, which is focused on the weakness handling and the strength increase, the Construction Education Study Program has an opportunity to be in the category of Industry Leader. The industrial area implies that overall, Construct-ion Education Study Program is managed on the industrial basis; for instance, the management, including the planning, values, and working cultures, is perceived to be like that of the industry. The working program that has been designed leads to the achievement of competitive quality instead of the regular program implementation. Construction Education Study Program should start departing from the conventional performance patterns to modern performance patterns.

In general, the performance of Construction Education Study Program has been good; however, it should also be admitted that there is still a gap between the expectation and the reality. Construction Education Study Program attained 50\% from $100 \%$ (maximum performance) and the figure was similar to almost all of the other criteria. Therefore, improvement should be made in all categories. More specific recommendations might be made based on the data which were attained from the questionnaires, which provided much information both quantitatively and qualitatively. In order to make the quantitative data have a significant impact, a team of designers should interpret the data qualitatively. 
Table 5. Recapitulation on the Results of Performance Measurement on the Engineering Education Study Program, Surakarta State University

\begin{tabular}{llccc}
\hline No & \multicolumn{1}{c}{ Category } & $\begin{array}{c}\text { Point According to } \\
\text { MBCfE }\end{array}$ & $\begin{array}{c}\text { Point from the Assessment } \\
\text { Results }\end{array}$ & Achievement (\%) \\
\hline 1 & Leadership & 120 & 93 & 77.50 \\
2 & Strategic Planing & 85 & 63 & 74.00 \\
3 & Customer & 85 & 62 & 73.00 \\
4 & Information \& Analysis & 90 & 64 & 71.00 \\
5 & Human Resources & 85 & 61 & 72.00 \\
6 & Process Management & 85 & 60 & 70.60 \\
7 & Results & 450 & $\mathbf{7 1 2}$ & 67.00 \\
\end{tabular}

Based on the results in Table 5, it is apparent that the measurement score attained by the Engineering Education Study Program is 712 points. The score implies that the Engineering Education Study Program earns Excellent title and belongs to Industry Leader category. Industry Leader category implies that Engineering Education Study Program has entered the industrial area of educational domain although only on the surface. The industrial area implies that the overall performance in the Engineering Education Study Program is managed based on the quality competence such as management, including the planning, values and working cultures; the competence has been created under the competitive performance.

In general, the performance of the Engineering Education Study Program is good although there is still a gap between the expectation and the reality. The prominence of the Engineering Education Study Program is in the leadership category; whose percentage is $77.50 \%$. The prominence in the leadership category is a very good capital for the organizational improvement. Regarding the importance of leadership category, Malcolm Baldridge has put the leadership category in the first place. The reason is that, basically, the objectives of an organization will be achieved if the leadership is implemented effectively (Kaplan, 2012, p.5).

However, in several categories, the researchers still found some gaps that were quite high; the gaps were found in the activity category. Therefore, improvement should become the first priority in the category. More specific recommendations might be provided based on the data attained from the questionnaires, which provided much information both quantitatively and qualitatively. Thereby, the questionnaires became the data that might be regarded as the information source and communication tools with other departments.

Based on the performance score in each study program, the policy-makers might analyze each criterion and employ the available criteria in order to improve the institutional performance. Table 6 shows the recapitulation of performance results for the other study programs.

Table 6. Recapitulation of Performance Measurement with Malcolm Baldridge

\begin{tabular}{|c|c|c|c|c|c|c|}
\hline \multirow{2}{*}{ No } & \multirow{2}{*}{ Category } & \multicolumn{5}{|c|}{ TEI } \\
\hline & & 3 & 4 & 5 & 6 & 7 \\
\hline 1 & Leadership & 82 & 72 & 85 & 73 & 91 \\
\hline 2 & Strategic Planing & 56 & 41 & 55 & 34 & 70 \\
\hline 3 & Customer & 55 & 45 & 58 & 39 & 62 \\
\hline 4 & Information \& Analysis & 55 & 42 & 64 & 33 & 74 \\
\hline 5 & Human Resources & 56 & 45 & 63 & 49 & 70 \\
\hline 6 & Process Management & 51 & 49 & 61 & 41 & 67 \\
\hline 7 & Results & 264 & 241 & 294 & 304 & 358 \\
\hline & Total & 619 & 535 & 680 & 573 & 793 \\
\hline
\end{tabular}




\section{Conclusions}

TEI belongs to the category of an organization with infinite resources. The role of TEI in Indonesia is very strategic in supporting economic development and the nation's competitive edge improvement. Therefore, TEI should work hard in order to be able to measure its performance so that the effectiveness of the educational implementation might be found. Based on the performance measurement by implementing Malcolm Baldridge Award, a study program might design a competitive plan in order to improve its educational quality.

\section{References}

Abraham, S.C. (2006). Strategic planning: A practical guide for competitive success. London: Thompson South-Western.

Allio, R. (1998). The practical srategiest: Business and corporate strategy for the 1990. Social Science-Elsevier, 21, 1041011.

Bryson, J.M. (1999). Perencanaan strategis bagi organisasi nirlaba [Strategic planning for non-profitable organization]. Yogyakar-ta: Pustaka Pelajar.

Cooper, D.R. \& William, E.C. (1996). Metode penelitian bisnis [Business research method]. Jakarta: Erlangga.

Department of National Education. (2010). Sistem penjaminan mutu Perguruan Tinggi [Higher education quality assurance system]. Jakarta: Dikti.

Handoko, T.H. (2003). Manajemen [Management]. Yogyakarta: Badan Penerbitan Fakultas Ekonomi.
Harry, S., \& Hertz. (2011). Criteria for performance. Retrieved from http://www.nist.gov

Indrajit, R.E., \& Djokopranoto, R. (2005). Manajemen strategis Perguruan Tinggi [Higher education strategic management]. Jakarta: Universitas Atmajaya.

Kaplan, R.S, \& Norton D.P. (1996). Translating strategy into action: The balanced scorecard. Boston: Harvard Business School Press.

Leslie, R. (2005). The art of trining and development: Effective planning. Jakarta: Gramedia Pustaka Utama.

National Institute of Standards and Technology. (2000). Baldrige national quality program 2000 education criteria for performance. Maryland: NIST.

Prosser, C.A. \& Quigley, T.H. (1950). Vocational education in a democracy (revised edition). Chicago: Amerian Technical Society.

Ridwan, A.S. (2008). Majamen mutu [Quality management]. Medan: Universitas Sumatera Utara.

Swasto, B. (1996). Pengembangan sumber daya manusia terhadap kinerja dan imbalan (1st ed.) [the development of human re-source towards performance and wage]. Malang: Universitas Brawijaya.

Wheelen, T.L. \& Hunger, J.D. (1996). Strategic management (5th ed.). Boston: Addison Wesley Publishing Company.

Wikipedia. (2008). Vocational education and training. Retrieved from http://en.wikipedia.org/wiki/Vocation al_Education_and_Training. 